\title{
DEMOCRACY AS COMPROMISE: AN ALTERNATIVE TO THE AGONISTIC VS. EPISTEMIC DIVIDE*
}

\author{
Gustavo H. Dalaqua** \\ http://orcid.org/0000-0002-9672-8703 \\ gustavodalaqua@yahoo.com.br
}

\begin{abstract}
The agonistic vs. epistemic dichotomy is fairly widespread in contemporary democratic theory and is endorsed by scholars as outstanding as Luis Felipe Miguel, Chantal Mouffe, and Nadia Urbinati. According to them, the idea that democratic deliberation can work as a rational exchange of arguments that aims at truth is incompatible with the recognition of conflict as a central feature of politics. In other words, the epistemic approach is bound to obliterate the agonistic and conflictive dimension of democracy. This article takes this dichotomized way of thinking to task by reconstructing the association between democracy and compromise made by John Stuart Mill, John Morley, and Hans Kelsen. It concludes that the conceptualization of democracy as compromise offers an alternative to the agonistic vs. epistemic divide that disconcerts a significant part of political philosophy today.
\end{abstract}

Keywords Democratic theory; compromise; epistemic democracy; John Stuart Mill; John Morley; Hans Kelsen.

* Article submitted on 16/06/2018 and accepted on 18/09/2018. This article is part of a doctoral dissertation, which was supervised by Alberto Ribeiro G. de Barros, co-supervised by Maria Isabel Limongi and examined by Cicero Romão de Araujo, Silvana de Souza Ramos, and Nadia Urbinati (see Dalaqua, 2019). I am grateful to all these scholars for their critical comments. I am also grateful to participants at the Compromise and Representation Conference, where a part of this article was presented in 2017 at the University of Copenhagen. This research received financial support from São Paulo Research Foundation, FAPESP grant \#2015/22251-0.

** Universidade Estadual do Paraná. União da Vitória, PR, Brasil. 
RESUMO Relativamente difundida na teoria democrática contemporânea, a dicotomia entre democracia epistêmica e democracia agonística é endossada por acadêmicos tão relevantes quanto Luis Felipe Miguel, Chantal Mouffe e Nadia Urbinati. De acordo com eles, a ideia de que a deliberação democrática possa funcionar como uma troca de argumentos racionais que visa à verdade é incompativel com o reconhecimento do conflito como um componente fulcral da política. Posto de outro modo, a abordagem epistêmica está fadada a obliterar a dimensão agonística e conflitiva da política. Por meio da reconstrução da associação entre democracia e compromisso feita por John Stuart Mill, John Morley e Hans Kelsen, este artigo contesta tal dicotomia e conclui que a conceptualização da democracia como compromisso oferece uma alternativa à dicotomia democracia epistêmica vs. agonismo que desconcerta uma parte significativa da filosofia politica hodierna.

Palavras-chave Teoria democrática; compromisso; democracia epistêmica; John Stuart Mill; John Morley; Hans Kelsen.

\section{Introduction}

The agonistic vs. epistemic divide disconcerts a significant part of contemporary democratic theory. Is democracy, as the agonistics claim, the realm of passionate conflicts? Or is it instead the realm of a reasonable consensus, a deliberation between impartial interlocutors who seek to discover truth? This either-or approach guides part of democratic theory today and is endorsed, in different degrees and under various guises, by scholars as outstanding as Luis Felipe Miguel, Chantal Mouffe, and Nadia Urbinati. ${ }^{1}$ After

1 I am aware that what I call "epistemic democracy" and "agonistic democracy" comprise a high number of theorists whose arguments differ from one another. Far from offering a nuanced account of the multifarious character of epistemic and agonistic democracy, here my goal is simply to reconstruct the agonistic vs. epistemic dichotomy as understood by Miguel, Mouffe, and Urbinati. For an assessment of the differences between theorists working within epistemic democracy, see Hélène Landemore (2017). On the different ways in which agonistic democracy can be conceived of, see Thomas Fossen (2008), Lois McNay (2014), Paulina Tambakaki (2015), Mark Wenman (2013) and Ed Wingenbach (2011). "Agonistic" comes from the Greek agon, which means struggle and contest, and is here employed as a synonym for "conflictive." I will use the expression "epistemic democracy" to denote any theory that deems democratic deliberation valuable because, inter alia, it can further knowledge and truth. My understanding of epistemic democracy is thus in agreement with David Estlund (2008, p. 108), a scholar who maintains that one can be an epistemic democratic without thereby claiming that democracy is valuable solely because of its epistemic-enhancing properties. Needless to say, the agonistic vs. epistemic divide that I identify in Miguel, Mouffe, and Urbinati does not imply that no difference exists between them. The critical exchange between Mouffe and Urbinati (2009) illuminates the disagreements between the two philosophers; on Miguel's difference in relation to Mouffe and Urbinati, see infra note three. 
briefly reviewing their arguments in the next section, my goal in sections three, four, and five will be to demonstrate how the association between democracy and compromise made by John Stuart Mill, John Morley, and Hans Kelsen offers an alternative to the agonistic vs. epistemic divide that disconcerts a significant part of democratic theory today.

\section{The agonistic vs. epistemic divide in Miguel, Mouffe, and Urbinati}

Miguel (2014, p. 77) refers to the so-called epistemic turn in democratic theory as "the consensualist turn [virada consensualista]."2 Under the influence of Habermas and Rawls, democratic theorists started to emphasize that political deliberation is a rational exercise that seeks to discover "the correct answers" to public issues and thus obliterated the constitutive role of passions and conflict in politics (Miguel, 2014, p. 281). According to Miguel (2016, pp. 45-6), the epistemic view of politics propagated by deliberative democracy ends up instituting "an unpolitical technocracy" that denies citizens' freedom. Since the "correct" outcome is independent of and prior to political discussion, citizens are not free to decide which course of action they will take. Instead, they are obliged to acquiesce willy-nilly to the "true" answer that their impartial and reason-driven deliberation reveals. This line of thinking easily justifies the substitution of democracy (the rule of the many) for epistocracy (the rule of the wise). After all, "if the intention is to find the right answers, a group of technocrats would certainly fare better than the ignorant many" (Miguel, 2014, p. 281).

As Miguel himself recognizes, his praise for agonistic democracy and repudiation of epistemic democracy were influenced by Mouffe's and Urbinati's works. ${ }^{3}$ To be sure, the agonistic vs. epistemic divide is also present in the political theory of both writers. In The Democratic Paradox, for instance, Mouffe (2000, p. 93) contends that epistemic democrats long for "a final rational solution," a hope that can only be "misguided" in politics. Focusing solely on reason, epistemic democrats negate "the crucial role played by passions

2 Unless otherwise noted, all translations are mine.

3 It should be borne in mind, however, that Miguel's appropriation of Mouffe and Urbinati is a critical one. Although he is encomiastic about their criticism of epistemic democracy, Miguel reproaches Urbinati and Mouffe for trying to stifle the expression of political conflict. He claims that Mouffe's distinction between agonism and antagonism smuggles a notion of consensus into her work that serves to contain conflict (Miguel, 2017, ch. 1) and, furthermore, accuses Urbinati's conception of representation as advocacy of being inimical to conflict and popular political participation (Miguel, 2014, ch. 7 and 2018, ch. 8). 
and affects" in politics (Mouffe, 2000, p. 95). ${ }^{4}$ Their major shortcoming is the attempt to ground democracy "on a type of rational agreement that would preclude the possibility of contestation" (Mouffe, 2000, p. 92). Like Miguel, Mouffe (2000, p. 65) argues that, by conflating democracy with a passionless deliberation that aims at "truth," epistemic theorists deprive people from the liberty to challenge political decisions. They thus excise conflict from politics and depoliticize democracy - that is to say, they annihilate "'the political', ... the dimension of antagonism that is inherent in human relations" (Mouffe, 2000, p. 101).

Mouffe's concept of the political descends from Carl Schmitt, a common reference for several contemporary agonistic democrats. Indeed, Schmitt's aspersion on the predominant political theory of his time resembles Miguel's, Mouffe's and Urbinati's critiques. ${ }^{5}$ He was one of the first philosophers in the modern period who established that an excessive emphasis on rational deliberation led scholars to misunderstand the nature of politics. In The Crisis of Parliamentary Democracy, Schmitt (1985, p. 35) argues that liberal proponents of parliamentary democracy such as J. S. Mill espouse a kind of political "rationalism" that has "truth" and "harmony" as its goals. Their rationalism is misleading insofar as it purports to put "discussion in place of force" (Schmitt, 1985, p. 49). ${ }^{6}$ According to Schmitt (2007, p. 28), liberalism's attempt "to transform the enemy... into a debating adversity" depoliticizes democracy because the rationalist deliberative model that ensues from it asphyxiates the conflictive essence of the political. Miguel's fear of an unpolitical technocracy and Mouffe's aversion to a depoliticized democracy find in Schmitt their common ancestor.

Miguel and Mouffe's dissatisfaction with epistemic democracy is also shared by Urbinati. In a series of letters she exchanged with Mouffe, Urbinati states that "deliberative [epistemic] democracy is the outcome of a rationalist project that aspires to eliminate political antagonism" (Mouffe and Urbinati,

4 A good assessment and critique of Mouffe's reason vs. passion dichotomy can be found in Mihaela Mihai (2014).

5 That is not to say, of course, that Miguel, Mouffe, and Urbinati are Schmitt's epigones, for, in truth, all three scholars cast animadversion on the German philosopher. One could say Miguel, Mouffe, and Urbinati rely on Schmitt only insofar as he offers a powerful critique of liberalism's rationalist tendencies. On the differences between Miguel and Schmitt, see Miguel (2017, ch. 1). For a clarification of Urbinati's and Mouffe's criticism of Schmitt, see Mouffe and Urbinati (2009).

6 For an earlier version of this critique, see James Fitzjames Stephen ([1874] 1993, p. 20-1). On Schmitt's critique of liberalism, see John P. McCormick (1997). As I explain in the next section, and as McCormick (1997, p. 172) himself points out, Schmitt's reading of Mill is not accurate. 
2009, pp. 807-8). ${ }^{7}$ Urbinati agrees with Mouffe that epistemic theorists "depoliticize democracy" because they want "to give more space to experts" and to institute "an unpolitical deliberation" bereft of passions and conflicts (Mouffe and Urbinati, 2009, p. 808). This critique has been reinforced in one her latest books, Democracy Disfigured: Opinion, Truth, and the People, where Urbinati (2014, p. 91) takes issue with "the epistemic transformation of political discourse in the deliberative theory of democracy." She maintains that the recent epistemic turn in the deliberative paradigm disfigures democracy. The disfigured version of democracy that this recent development within the deliberative approach has provoked corresponds to what she calls "unpolitical democracy" (Urbinati, 2014, p. 81).

Properly speaking, unpolitical democracy should not be considered democratic because it "tend[s] to neutralize" the basic feature of democracy, viz. "dispute" (Urbinati, 2014, p. 81). By equating democracy with an impartial exchange of arguments between "reasonable" interlocutors who are eager to reach an "objective and dispassionate truth," deliberative democrats make "politics become inhospitable to contestation and liberty" (Urbinati, 2014, pp. 123, 99). Truth, as Urbinati (2014, p. 105) sees it, carries within itself an element of coercion; a "scientist ... capitulates before truth." According to her account, truth is not something we actively construct. Rather, it is something before which we can simply "acquiesce" (Urbinati 2014, p. 105). In the place of the depoliticized technocracy promoted by epistemic democracy, Urbinati proposes a democratic theory that is truly political because it recognizes passions and conflict as key features of democracy.

This brief overview of Miguel, Mouffe, and Urbinati brings to the fore one common thesis that lurks behind the epistemic vs. agonistic dichotomy they endorse, namely, the thesis that characterizing democracy as a deliberative quest for truth denies the political role played by passions and conflict. The idea that one could acknowledge the epistemic properties of democratic deliberation without undermining the constitutive role of passions and conflict in politics does not appear in Miguel's, Mouffe's, and Urbinati's writings. This absence exposes a limitation of their thinking, for the epistemic and agonistic

7 I add "epistemic" because, like Miguel and Mouffe, Urbinati usually employs "epistemic" and "deliberative" synonymously when criticizing epistemic democracy. According to her, epistemic democracy "is a development from within the deliberative theory of democracy" (Urbinati, 2014, p. 93). By excoriating epistemic democracy, Urbinati thus inevitably sets herself apart from deliberative democracy, for, according to her own definition, epistemic democracy is a subfield of deliberative democracy. This is worth mentioning because Urbinati's emphasis on proceduralism could lead one to identify her as a kind of Habermasian deliberative democrat. Yet as Dario Castiglione observes, given Urbinati's stress on political conflict, such identification would be imprecise (Accetti et al., 2016, p. 219; see also Urbinati, 2006, p. 29). 
dimensions of democracy can be compatible. In order to prove that, one must turn to the characterization of democracy as compromise found in the political philosophy of Mill, Morley, and Kelsen.

\title{
3. Democracy and compromise in Mill
}

\begin{abstract}
One of the most indispensable requisites in the practical conduct of politics, especially in the management of free institutions, is conciliation; a readiness to compromise; a willingness to concede something to opponents, and to shape good measures so as to be as little offensive as possible to persons of opposite views; and of this salutary habit, the mutual give and take (as it has been called) between two Houses is a perpetual school; useful as such even now, and its utility would probably be even more felt, in a more democratic constitution of the Legislature. (CW XIX, p. 514) ${ }^{8}$
\end{abstract}

In Considerations on Representative Government, Mill maintains that compromise is a sine qua non for the well-functioning of a representative democracy. More than simply a form of government, democracy requires for Mill a specific "way of life," one in which citizens are willing to scrutinize their opinions and beliefs (Frías, 2006, p. 80). Such willingness goes hand in hand with the recognition of the fallible character of every human opinion. After all, the infallibility of an opinion implies that anything opposing it is necessarily wrong and ipso facto unworthy of attention.

The critical lifestyle Mill associates with democracy is intimately connected with his sociological account of the democratic regime. Influenced by "Pericles' Funeral Oration," Mill understood that democracy is inextricably bound up with social diversity (CW XI, p. 319). As highlighted by Pericles, democracy represents not only a form of government, but also a form of society where the uniqueness of each citizen is respected and promoted (Thucydides, 1982, pp. 109ff). Mill portrayed democracy in stark contrast to China, which in his view was a proto-totalitarian society that violently sought to expurgate every form of individual difference and conflict in order to bring about total social homogeneity. ${ }^{9}$ Democracy is the regime where conflict and human diversity are a matter of celebration, not of condemnation.

8 Following common practice among Mill scholars, references to The Collected Works of John Stuart Mill are written as follows: CW VII, p. 313, for Collected Works, volume VII, page 313. Mill's depiction of compromise as a mutual give and take is reminiscent of Edmund Burke's (1987, p. 126) famous encomium on compromise: "All government, indeed every human benefit and enjoyment, every virtue, and every prudent act, is founded on compromise and barter. We balance inconveniences; we give and take; we remit some rights, that we may enjoy others."

9 For a critical assessment of Mill's reading of China, see Jennifer Pitts (2005, ch. 5). 
Compromise is indispensable to democracy insofar as it fosters a non-dogmatic approach to politics. The "general habit and practice ... of compromise" leads to the appreciation of "discordance between principles and practice, not only as the natural, but as the desirable state" of political life (CW XX, p. 331). Compromise is conducive to a democratic ethos because it makes people become used to disagreement and conflict. If by consensus we mean complete unanimity whereby further disagreements are suppressed once and for all, then it should be said that democracy for Mill is the regime of compromise, not of consensus. ${ }^{10}$

Compromise differs from consensus precisely because it always leaves a residue of dissatisfaction. From one's private perspective, a compromise is a second-best solution inasmuch as it requires sacrificing part of one's initial claim in order to accommodate it with opposing demands (Ankersmit, 2002, p. 209; Bellamy, 1999, p. 102; Canivez, 2010, p. 97; Fumurescu, 2013, p. 72; Gutmann and Thompson, 2012, p. 10). Yet from a political standpoint, compromises are certainly not second-best alternatives to a unanimous consensus. Unlike consensus, compromises allow representatives to graft onto legislative decisions the plurality of views held by citizens, thus furthering the democratic ideal that each citizen should have equal power to influence political affairs (Rostbøll, 2017, pp. 619-21).

Mill's appraisal of compromise is related to his critique of majoritarian democracy. A regime where majority rule is the sole criterion for the promulgation of public policies is a falsification of democracy because, in practice, it deprives minorities of political power. Mill's endorsement of the "spirit of compromise" was related to his understanding of democracy as a regime that uses majority rule, but that is not defined by the rule of the majority tout court (CW XIX, p. 344). ${ }^{11}$ His characterization of democracy as

10 The distinction between compromise and consensus is not unusual among scholars who theorize the relationship between democracy and compromise (Ankersmit, 2002, ch. 5 and Bellamy, 1999, ch. 4). By claiming that compromise differs from consensus because, unlike the latter, it does not hinder the manifestation of political conflict, political theorists reinforce a negative connotation that became part of the semantic horizon of "consensus" in the English language. As Raymond Williams (1983, p. 77) emphasizes, the word "consensus" started to be used in modern English "to describe deliberate evasion of basic conflicts of principle [in politics]." Nevertheless, "consensus" can be used without invoking such negative connotation. In the Dizionario di politica, for instance, consenso is cast in a positive light as a political agreement that can assume different degrees. According to the definition given in that dictionary, consenso is a spectrum rather than a dichotomy (Sani, 1983). Political decisions are never totally consensual; rather, they are more or less consensual, and so in this sense one is led to recognize that the word "consensus" can be defined in such a way as to become capable of harboring conflict and compromise. Even though I recognize such possibility, in this article, I employ the term "consensus" in its more usual sense underlined by Williams and follow Frank Ankersmit's and Richard Bellamy's distinction between compromise and consensus, meaning by the latter a type of unanimous concurrence that tends to elide political conflict.

11 On the difference between democracy as compromise and "simple majority rule," see Bellamy (2018, p. 318). 
compromise indicates that a regime where the majority can "take it all" should not be deemed democratic. Rather than signifying the rule of the majority over all the rest, democracy should be identified as "the government of the whole people by the whole people" (CW XIX, p. 448). Compromise fulfils the normative demand of democracy understood as self-government inasmuch as it grants political power both to majority and minority groups.

Since they always leave a residue of dissatisfaction, compromises are inevitably temporary. They deny the idea that a final answer can be found for political issues and acknowledge that public decisions should be open to contestation and amendment. Mill's praise of compromise is related to his constructivist conception of representation. ${ }^{12}$ For him, political representation does not simply reproduce pre-given ideas and identities, but also constructs them through the practice of compromise. Thus, Mill was against imperative mandates, a proposal that is deeply connected with the mirroring conception of representation.

For most of those who support imperative mandates, the role of the representative is only to mirror and reflect her constituents' views, which are entirely formed and static. Mill considered imperative mandates deleterious because they ossify political preferences and obstruct the practice of compromise. Democratic deliberation requires participants to cultivate a nondogmatic stance and to recognize themselves as fallible beings. To the extent it is dialogical, deliberation must not be equated with a succession of monologues that do not communicate because their positions are fully formed in advance. Democratic deliberation is a dialogue in which participants are willing to take into account others' positions and even to change their initial assumptions if need be. Representatives cannot foresee every opinion that will be fleshed out in the assembly. Thus it is unreasonable to prohibit them from changing their views. In short, Mill thought imperative mandates should not be adopted because they deny the very notion of democratic deliberation as a site of (re) formulation of new practices and ideas. ${ }^{13}$ In a representative democracy, the role of the political assembly is "to be at once the nation's Committee of Grievances, and its Congress of Opinions; an arena in which not only the general opinion

12 On Mill's representative constructivism, see Gustavo Hessmann Dalaqua (2018). Following Lisa Disch (2015, p. 490), I employ the term "constructivist" to convey "the idea that acts of representation do not refer to the represented in any straightforward way but work to constitute the represented as unified and (typically) as a bearer of interests and demands." My use of the word is also indebted to Pierre Rosanvallon (1998, p. 231), who uses the term constructive to designate the power representation has to construct new political identities. For an earlier version of the argument, see Rosanvallon (1985, p. 56).

13 For representative governments that are not properly democratic, however, Mill thought the use of imperative mandates was acceptable (see CW XIX, p. 508). 
of the nation, but that of every section of it ... can produce itself in full light" (CW XIX, p. 432, emphasis added). Political representation has constructivist power because the struggle between opposing perspectives in the assembly leads to compromise, which in turn produces new ideas, beliefs, and opinions that change the way citizens reason and see themselves.

The conception of political representation that springs from democracy as compromise belies the idea that society is an aggregate of dissociated atoms. Likewise, it refutes the thesis that citizens would be nothing but isolated beings with pre-given and unchangeable preferences and, moreover, sheds light on the fact that citizens (trans)form their preferences and identities collectively. The ideas that representatives express in the assembly oftentimes result from a previous union of individuals. Conversely, their unfolding inside the assembly tends to promote the gathering of other individuals, either in support or opposition to them. Ultimately, both the representative and the represented possess the power to construct the political identity of one another.

According to Mill, those who are used to compromise end up realizing that the crystallization of any given coalition of political forces is detrimental, for each balance of power creates a new group of underdogs who would benefit from unsettling the compromise that has been settled. Whereas compromises should be seen as normal outcomes of democratic deliberation, the existence of total unanimity must be, according to Mill, looked upon with distrust (Ten, 1980, p. 71). In a pluralistic democracy, total unanimity portends the existence of oppression. Mill's presupposition is that democratic citizens living under "an atmosphere of freedom" will inevitably have conflictive political ideas (CW XVIII, p. 267). He believes that conflict and disagreement are ineradicable in pluralistic democracies and affirms that compromise is the best way to cope with them.

To understand why compromise copes better with conflict than consensus, it is worth remembering Mouffe's criticism of epistemic democracy. In her view, epistemic democrats' longing for a "consensus without exclusion" is misguided because affirming that one political decision was based on a total consensus camouflages the fact that, in truth, some people did not agree with the final outcome of the deliberative process (Mouffe, 2000, p. 48). Mouffe's critique, however, does not apply to compromise. Countenancing compromises entails recognizing that some views were indeed excluded and that, therefore, some demands were not satisfied by the decision made. Here it is useful to recall Mill's definition of compromise as "the art of sacrificing the non-essential to preserve the essential" (CW I, p. 87). Compromise is the result of a sacrifice. It has a constitutive outside, so to speak, a set of excluded rival demands 
that sooner or later will destabilize it and thus prompt the creation of a new compromise. By making exclusion visible, a politics based on compromise favors and incites the contestation of public policies and of the given hegemonic order they represent. Far from attempting to eliminate disagreement, the "spirit of compromise" recommended by Mill considers conflict to be a valuable source of political creativity in a pluralistic democracy (CW XIX, p. 344). Compromise is an agreement that values disagreement, a type of concurrence that does not elude conflict.

Mill's philosophy of compromise shows that the main charge raised by Miguel, Mouffe, and Urbinati against epistemic democracy does not apply to his theory of democracy. As Urbinati (2002, p. 82) herself recognizes, Mill offers an "agonistic model" of democracy which is opposed to the epistemic model of "deliberative democracy" she is so critical of. Unlike the latter, agonistic democracy for Urbinati (2002, p. 82) does not envisage political deliberation "as a process of public reasoning that eventually produces a 'true' outcome." Here one comes up against an earlier version of the epistemic vs. agonistic dichotomy which Urbinati (2014) set forth in Democracy Disfigured: those who conceive democratic deliberation as a rational exchange of arguments that aims at truth deny conflict and force citizens to "relinquish the passions that fuel them and that impede the attainment of truth" (Urbinati, 2002, p. 82). According to Urbinati, since Mill recognizes the constitutive role of conflict in politics, we necessarily have to oppose his political theory to the epistemicdeliberative model she disparages.

Urbinati's dichotomized way of thinking precludes her from acknowledging that, in fact, Mill does presume democratic deliberation to have epistemic properties. To be sure, my contention is that, once we pay attention to Mill's, Morley's, and Kelsen's alliance between democracy and compromise, the whole agonistic vs. epistemic dichotomy advanced by Miguel, Mouffe, and Urbinati seems a bit exaggerated. A theory that emphasizes the rational and epistemic dimension of democracy is not doomed to neglect the fundamental role performed by passions and conflict in political life. Reason and passion, truth and conflict, are not necessarily antithetical. ${ }^{14}$

"Truth, in the great practical concerns of life, is so much a question of the reconciling and combining of opposites ... and it has to be made by the rough process of a struggle between combatants fighting under hostile banners" (CW XVIII, pp. 253-54). In chapter two of On Liberty, Mill explains that there are 
two kinds of truths: one that excludes objections and another that develops out of objections. The first type of truth pertains to mathematics and is immutable. The second one, by contrast, is always changing and belongs to the political realm. In politics, "the conflicting doctrines, instead of being one true and the other false, [usually] share the truth between them" (CW XVIII, p. 252). ${ }^{15}$ In Mill's political theory, agonistic democracy goes pari passu with epistemic democracy.

What Mill calls "political truth" is not an extra-political criterion that predetermines the results of democratic deliberation (CW XIX, p. 418). According to him, "only through diversity of opinion is there ... a chance of fair play to all sides of the truth" (CW XVIII, p. 254). Many-sided, political truth is spread among citizens and it is only by deliberating and compromising our views with the views of other citizens that we can construct truth. Mill's conception of public and parliamentary deliberation is based on a "perspectivist theory of knowledge" (Habermas, 2014, p. 314). To know the truth of any political phenomenon, one needs to study the various perspectives under which this phenomenon may be examined. What is characteristic of perspectivist epistemologies, as James Conant (2006, p. 51) and Linda Zerilli (2016, p. 268) expound, is their bold affirmation of the interplay between objectivity and subjectivity: it is only by collating and contrasting the different (subjective) perspectives on something through public debate that (objective) knowledge can be constructed. Since they address topics that are everybody's concern, acquiring complete knowledge about political issues requires taking into account the different perspectives through which they can be viewed and experienced. Epistemic democracy becomes thus a justification for democratic inclusion: if a society aims at a more correct and truer political decision, public debate should be equally open to all.

One of the goals of democratic deliberation for Mill is to produce public policies that are wiser or more correct insofar as they deal more efficiently with collective problems. ${ }^{16}$ Compromises are required in order to produce wiser public policies. The process of combining and balancing rival perspectives on how political problems should be confronted is precisely the crux of

15 I add "usually" to avoid the impression that Mill always thought this was the case. Obviously, not every political view was equally correct for him. See infra note seventeen.

16 I am endorsing here the pragmatist conception of truth (present in chapter two of On Liberty and in Morley's On Compromise) which posits that truth corresponds to the assertions that so far have proved most efficient in solving collective problems. As Richard Rorty (2007, p. 34) highlights, the pragmatist theory of truth that Mill associates with political compromise can fortify "our devotion to democracy." For a fuller exploration between Millian democracy and pragmatism, see Dalaqua (2017). 
compromise. Every compromise, Mill argues in Auguste Comte and Positivism, should constitute a "juste milieu" between conflicting arguments (CW X, pp. 263-64). This juste milieu or fair balance is precisely what, in other works, Mill refers to as political truth. Compromise, a democratic practice that feeds on conflict and that is unthinkable without it, is a mechanism for constructing political truth.

Before leaving aside Mill's theory of compromise, it should be observed that Mill does not consider all kinds of compromise desirable. As noted earlier, Mill's appraisal of compromise is related with his defense of democracy, and so compromises for him are valued to the extent that they are conducive to democracy. A democratic champion like Mill would never accept a compromise that disrespected the basic democratic principles of liberty and equality (Thompson, 2007, pp. 192-93) ${ }^{17}$ As we will see in the next section, the same was true of Morley, who also believed that compromises were legitimate insofar as they promoted a democratic ethos.

\section{Democracy and compromise in Morley}

Originally published in 1874, Morley's On Compromise is probably the only book-length text of his time to analyze the centrality of compromise in modern democracy. This is certainly different from Mill, who never devoted an entire book to the topic. Morley's conception of compromise does not need to be pieced together from various passages of his oeuvre. An examination of the main points of $O n$ Compromise suffices to present an adequate explanation of Morley's theory of compromise.

Morley $(1898$, p. 1) commences his book by defining compromise as "the practice of the various arts of accommodation." Not only the definition, but also the way in which he associates the practice of compromise with "truth" and opposes it to "fanaticism," reveal from the outset Morley's (1898, p. 4) indebtedness to Mill. ${ }^{18}$ Morley (1898, p. 4) reserves the term "fanatic" for

17 Mill's distaste for compromises that disrespect the principle of equality, for instance, was evident in his reaction to Governor Eyre's response to the Morant Bay rebellion (Miller, 2005). Mill refused to compromise with the idea, endorsed by many political groups in Victorian Britain, that Governor Eyre should not be indicted for his disproportionate response to the Jamaicans' rebellion. Such view was completely wrong for Mill because it did not deal adequately with the political crisis that Governor Eyre's misdemeanor had produced. Paraphrasing Avishai Margalit (2010, p. 10), one could say that a compromise that accepted and justified Governor Eyre's inhuman treatment of Jamaicans would be nothing but "a rotten political compromise."

18 Indeed, the last section of Morley's book is entirely dedicated to Mill's political philosophy. Mill is quoted more than a dozen times in On Compromise and, as John Wyon Burrow (1988, p. 22) underscores, the similarities between their political theories reveal that Morley was "Mill's disciple." On the influence of Mill's political theory on Morley's, see also J. F. Stephen ([1874] 1993, p. 229). 
anyone who "injures good causes by refusing timely and harmless concession; by irritating prejudices that a wiser way of urging his own opinion might have turned aside." Morley here alludes to the practice of "trimming," which for Mill - and for contemporary scholars such as Gutmann and Thompson (2012, p. 10) - is a fundamental element of compromise (CW XXVI, p. 370).

Trimming makes compromise possible by minimizing opposition through strategic behavior. Take for instance Mill's political performance during the parliamentary debates preceding the approval of the Reform Act of 1867, which expanded the franchise to more than thirty-five percent of the adult male population in England (Kahan, 2003, p. 122). Mill knew that the support of the Conservative Party, which at the time had the majority in the House, was crucial to the measure's success. Faced with that circumstance, he claimed the Reform Act was a corollary "from the class theory, which we all know is the Conservative view of the constitution" (CW XXVIII, p. 61). The proletariat constituted a class and, as such, was entitled to its own representatives.

Mill was canny and invoked the conservative class theory of representation to defend the expansion of the suffrage. He insisted that the democratic aspect of the measure was not under discussion and reproached a fellow politician for arguing that the Reform Act was good because it promoted democracy. In that circumstance, justifying the Reform Act on democratic grounds was a bad strategy because conservative politicians were afraid of democracy. To avoid arousing antidemocratic biases, Mill was adamant that the Reform Act was an issue of class representation, not of democracy (CW XXVIII, p. 61). As a "democratic champion," Mill supported the expansion of the franchise, for he knew that, the larger the franchise, the more democratic England would become (CW I, p. 66). Yet, for the sake of the measure, he was willing to compromise and thus temporarily refrained from affirming the value of democracy. ${ }^{19}$ By turning aside unnecessary opposition, Mill's compromise avoided legislative gridlock and helped strengthen democracy in England. As Morley (1898, p. 229) explains, identifying compromise as a fundamental feature of politics

means . . . that we ought never to press our ideas up to their remotest logical issues, without reference to the conditions in which we are applying them. In politics we have an art. Success in politics, as in every other art, obviously before all else implies both knowledge of the material with which we have to deal, and also such concession as is necessary to the qualities of the material.

19 One could say Mill's strategy was successful, for, as Janice Carlisle (1999, p. 159) points out, his speech in defense of the Reform Act was very popular among conservative politicians and was instrumental in persuading them to approve the measure. 
Compromise stresses the rhetorical nature of political argumentation. A rhetorical demonstration must be given in a contingent and contextual manner because, since persuasion is its goal, it has always to take into account its specific audience, the "material" with which it has to deal (Morley, 1898, p. 229). The material Morley (1898, p. 71) speaks of is a mixture of "reason, affection, and will." Those who deem compromise a vital aspect of democracy know that passions and affects play a pivotal role in political deliberation. Reason alone is insufficient to move the will, and if one wishes to persuade others to make a decision and follow a course of action, one needs to mobilize their passions. ${ }^{20}$

When Morley contends that achieving a compromise demands enticing citizens' passions, he does not demean the importance of reason in politics. A successful compromise has to appeal both to passion and reason. Compromise puts into question the passion vs. reason dichotomy inasmuch as it claims that, in order to be accepted by a group of people, a political proposal ought to "stir their love of truth" (Morley, 1898, p. 69). In a democratic debate riven by conflict, convincing the majority to accept a proposal can happen only if its proponent succeeds in making others feel the proposal is true - which is to say, that it deals efficiently with a collective problem. Far from being simply a rational matter, political truth is an object of passionate investment for Morley.

As we can see, the concept of truth is also a major presence in $O n$ Compromise. The habit of compromise, Morley (1898, p. 18) maintains, springs "from a deep sense of the relative and provisional quality of truth." Compromise involves jettisoning the idea that politics is the realm of absolute truth: "The disciples of the relative may afford to compromise. The disciples of the absolute, never" (Morley, 1898, p. 56). Influenced by Mill, Morley (1898, p. 80) holds that political truth is scattered among citizens and that compromise is an attempt to combine every "particle of truth."

Fanaticism is anathema to compromise insofar as "faith in our infallibility is necessarily bound up with intolerance," and compromise can only work properly with tolerance (Morley, 1898, p. 242). Following Mill, Morley (1898, p. 87) claims that the practice of compromise produces "effects upon the mind and character of the person compromising." Those who are used to compromise admit the fallibility of their beliefs and are willing to critically examine their current set of political opinions (Morley, 1898, p. 132). They welcome objections to their beliefs because they are aware that being challenged is the best way to construct truth. As the last section of On Compromise makes clear, 
agonistic "discussion is the only certain means of preserving the freshness of truth in men's minds, and the vitality of its influence upon their conduct and motives" (Morley, 1898, p. 272). To preserve our vital, passionate grasp of political truth, we need to balance conflicting positions and compromise. ${ }^{21}$

In politics, the combination or compromise among the different "elements of truth" is bound to be provisional because, as public problems are always changing, so is political truth (Morley, 1898, p. 75). According to Morley (1898, p. 232), a compromise is bad when its "instalment [is seen] as final, followed by the virtual abandonment of hope and effort." Compromises are deleterious when they ossify a given hegemonic constellation of power in such a way as to inhibit further contestation and social improvement (Morley, 1898, pp. 230-31). As Mill would put it, a compromise that hinders the betterment of humankind should not be accepted (Thompson, 2007, p. 177).

For both Mill and Morley, citizens can develop themselves only when they are allowed to criticize the norms and beliefs that organize their lives. A compromise that makes citizens "abstain from inquiry" and simply reinforces the status quo is noxious because it dwarfs citizens' self-development (Morley, 1898, p. 110). Conversely, the practice of compromise is salutary when it encourages public critique by instilling in citizens the perception that they are all equally fallible. Since it preaches we could all be equally wrong, the epistemological fallibilism that ensues from Mill's and Morley's theory of compromise justifies the need for democratic deliberation. None of us is in possession of an absolute truth and thus we all should examine and, if need be, compromise our views when confronted with objections from others. As the next section indicates, both democracy and compromise favor the idea that transcendental foundations and absolute certainty are not available in politics.

\section{Democracy and compromise in Kelsen}

Published in 1929, Kelsen's The Essence and Value of Democracy strengthens Mill's and Morley's link between compromise and democracy:

$[\mathrm{T}]$ he aim of the entire parliamentary process is to achieve a compromise between opposing interests, to produce a resultant of the various conflicting social forces. This process guarantees that the various interests of the groups represented in parliament are given a voice, that they are able to manifest themselves as such in a public proceeding. If the specifically dialectical process within parliament has a deeper meaning, then 
surely it is that the opposition of the thesis and antithesis of political interests somehow results in a synthesis. Here, however, this can only refer to a compromise, and not . . . a "higher" absolute truth. (Kelsen, 2013, p. 70)

One of the aims of representative democracy for Kelsen is to utilize social conflict in a productive way. Rather than aiming at a final consensus or a higher absolute truth, representative democracy acknowledges conflict as an "unavoidable fact" of politics and seeks to institutionalize its expression through the proportional representation of antagonistic political groups (Kelsen, 2013, p. 40). Like Mill, Kelsen believed that the representative assembly should be "the place where the opinions which divide the public on great subjects of national interest meet in a common arena [and] do battle" (CW XIX, p. 348). In order to guarantee the perpetuity of conflict in the legislative process, both Mill and Kelsen advocated for the proportional representation of every political group (cf. CW XIX, p. 452 and Kelsen, 2013, p. 72).

For both Kelsen and Mill, democracy without proportional representation could easily degenerate into the tyranny of the majority. If democracy is to fulfil its normative demand of realizing self-government, political decisions must result from compromises made among the various political groups that the demos comprises. A politics based on compromise unites the agonistic and deliberative strands of democracy, for it allows the extant antagonism in society to unfold in a discursive manner. It permits political groups to manifest their rival passions inside political institutions, but at the same time forces them to deliberate and reach provisory agreements (i.e., compromises).

Like Mill and Morley, Kelsen claims that compromise and democracy are deeply intertwined because both presume a non-dogmatic approach to politics:

He who views absolute truth and absolute values as inaccessible to the human understanding cognition must deem not only his own, but also the opinion of others at least as feasible. The idea of democracy thus presupposes relativism as its worldview. ... Similarly, there is nothing more characteristic of the relativistic worldview than the tendency to seek a balance between two opposing standpoints, neither of which can by itself be adopted fully, without reservation, and in complete negation of the other. (Kelsen, 2013, p. 103)

Kelsen understands that democracy and compromise are, respectively, the political regime and practice that spring from relativism - or, as we have called it thus far, fallibilism. ${ }^{22}$ Democratic citizens are aware of the relative and fallible 
character that every individual political perspective necessarily has. Precisely for that reason, they acknowledge that public decisions "must be the result of a compromise between opposing interests" (Kelsen, 2013, p. 40).

As this article has underscored, political theorists who posit an inner link between democracy and compromise recognize conflict and passion as core features of political life. However, contra the agonistic vs. epistemic dichotomy, such recognition is not incompatible with an appreciation of the political relevance of rational deliberation. This is true not only of Mill and Morley, as we have seen, but also of Kelsen. Indeed, it would be imprecise to affirm that Mill's theory of compromise differs from Kelsen's because, whereas the former attributes epistemic properties to political deliberation, the latter does not. In the same chapter where he explains that democracy and compromise both presume relativism, Kelsen (2013, pp. 103-4) makes clear that acknowledging the relative and partial character of every human cognition does not entail immuring politics from truth:

The belief in absolute truth and absolute values furnishes the precondition for a metaphysical and, in particular, a religious-mystical worldview. The negation of this precondition, however, is the viewpoint that only relative truths and values are accessible to human cognition and that, consequently, every truth and every value must - just as the human individual who finds them - be prepared to abdicate its position and make room for others. ... He who only relies on earthly truth and only allows human knowledge to direct social policy can justify the coercion, which the realization of that policy inevitably requires, in no other way than with the assent of at least the majority of those who are supposed to benefit from the coercive order.... This is the actual meaning behind the political system we call democracy. ${ }^{23}$

In Kelsen's democratic theory, the refusal of absolute truth does not divorce truth and politics. Kelsen concedes that, as long as they are not of an absolute kind, truth claims can be invoked in democratic deliberation. Relative or "earthily truth" can justify public policies in a democracy because, unlike absolute truth, relative truth is conducive to compromise (Kelsen, 2013, p. 104). As Kelsen (2000, p. 134) explains in the final section of Das Problem des Parlamentarismus, philosophical relativism - the doctrine that denies the existence of an absolute, immutable, and everlasting Truth and, instead, holds that truth is a human-made artefact which results from a compromise, a juste milieu between opposing arguments - corresponds precisely to "democratic parliamentarism.” Thus, Kelsen (2000, p. 133) claims Schmitt misunderstood recognizes only relative truth." Here it is also clear that relativism denies only absolute truth, not truth tout court. 
democratic parliamentarism when, in The Crisis of Parliamentary Democracy, the latter asserted that parliamentary deliberation aspired to "absolute truth." When politicians deliberate in a parliamentary democracy, their target is to construct a relative and provisional truth, a compromise that is able to address collective problems in a more or less satisfactory way. ${ }^{24}$

Kelsenian relativism should not be read as an attempt to insulate democracy from truth tout court. As Vinx (2007, pp. 134-35) argues in Hans Kelsen's Pure Theory of Law, "an adequate understanding of the relation between democracy and relativism ... does not lead to the conclusion that moral truth-claims must be checked at the door of politics." It is one thing to affirm that human values and truth claims are relative, and yet another to argue that they are not available for political debate (Kelsen, 1955, p. 96). When Kelsen denies that political deliberation should aim at absolute truth, he does not divorce truth and politics, for he still affirms that relative truth is within the purview of democracy. Even if citizens can never achieve an absolute truth that would impart "pure" objectivity to their deliberation, the quest for relative truth nevertheless remains an important concern for them.

\section{Conclusion}

This paper has argued that the association between compromise and democracy made by Mill, Morley, and Kelsen reveals that the agonistic vs. epistemic divide which is endorsed by democratic theorists as outstanding as Miguel, Mouffe, and Urbinati should be taken with a grain of salt. What Mill's, Morley's, and Kelsen's concept of compromise has to teach for contemporary scholars is that the epistemic model of democracy as a rational exchange of arguments that seeks to construct truth can indeed incorporate conflict and contestation as defining features of the democratic process. Their concept of compromise, in sum, offers an alternative to the current agonistic vs. epistemic antithesis that is espoused by a significant number of democratic theorists today.

24 In the wake of Urbinati and Accetti's (2013, p. 8) reading of Kelsen, one could contend that whenever politics becomes the realm of truth, political autonomy is curtailed inasmuch as citizens lose their freedom to establish what course of action they are to adopt. Citizens cannot establish their own laws because the decision they will reach simply follows an immutable standard of truth that is prior to and independent of their political will. What such contention neglects to mention is that this Platonic kind of truth, which the Czech philosopher doubtless repudiated, was not the only type of truth for Kelsen. Political truth can be interpreted in such a way as to become compatible with political autonomy, and that is precisely what Kelsen $(2013$, p. 104) does when he advances the concept of "relative truth." 


\section{References}

ACCETTI, C. I. et al. "Debating representative democracy." Contemporary Political Theory, Vol. 15, Nr. 2, pp. 205-242, 2016.

ANKERSMIT, F. R. "Political Representation." Stanford: Stanford University Press, 2002.

BAUME, S. "What place should compromise be given in democracy? A reflection on Hans Kelsen's contribution.” Négociations, Vol. 27, Nr. 1, pp. 73-89, 2017.

BELLAMY, R. "Liberalism and Pluralism: Towards a Politics of Compromise." London: Routledge, 1999.

."Majority rule, compromise and the democratic legitimacy of referendums."

Swiss Political Science Review, Vol. 24, Nr. 3, pp. 312-319, 2018.

BURKE, E. "The Political Philosophy of Edmund Burke.” Harlow: Longman, 1987.

BURROW, J. W. "Whigs and Liberals: Continuity and Change in English Political Thought." Oxford: Clarendon Press, 1988.

CANIVEZ, P. “Democracy and compromise." In: D. M. Gabbay et al. (eds.). Approaches to Legal Rationality. Dordrecht: Springer, 2010, pp. 97-118.

CARLISLE, J. "Mr. J. Stuart Mill, M. P., and the character of the working classes." In: E. Eisenach (ed.). Mill and the Moral Character of Liberalism. Pennsylvania: Pennsylvania University Press, 1999, pp. 143-168.

CONANT, J. "The dialectic of perspectivism, II." Sats - Nordic Journal of Philosophy, Vol. 7, Nr. 1, pp. 6-57, 2006.

DALAQUA, G. H. "Democracy and truth: A contingent defense of epistemic democracy." Critical Review, Vol. 29, Nr. 1, pp. 49-71, 2017.

. "What makes representative constructivism democratic?". PERI, Vol. 10, Nr.

2, pp. 100-122, 2018.

. "Democracia representativa, consenso e conflito em J. S. Mill." Tese de Doutorado em Filosofia. Faculdade de Filosofia, Letras e Ciências Humanas, Universidade de São Paulo, 2019.

DISCH, L. "The 'constructivist turn' in democratic representation." Constellations, Vol. 22, Nr. 4, pp. 487-489, 2015.

ESTLUND, D. "Democratic Authority: A Philosophical Framework." Princeton, NJ: Princeton University Press, 2008.

FOSSEN, T. "Agonistic critiques of liberalism: Perfection and emancipation." Contemporary Political Theory, Vol. 7, Nr. 4, pp. 376-394, 2008.

FRÍAS, S. C. "John Stuart Mill: Un modelo ético y antropológico de democracia." Telos: Revista Iberoamericana de Estudios Utilitaristas, Vol. 15, Nr. 1, pp. 53-84, 2006. FUMURESCU, A. "Compromise: A Political and Philosophical History." Cambridge: Cambridge University Press, 2013.

GUTMANN, A. and THOMPSON, D. "The Spirit of Compromise: Why Governing Demands It and Campaigning Undermines It.” Princeton, NJ: Princeton University Press, 2012.

HABERMAS, J. "Mudança estrutural da esfera pública: Investigações sobre uma categoria da sociedade burguesa.” Trans. D. L. Werle. São Paulo: Editora Unesp, 2014. 
HUME, D. “Treatise of Human Nature.” Amherst, NY: Prometheus Books, 1992.

KAHAN, A. "Liberalism in Nineteenth-century Europe." Basingstoke, Hampshire: Palgrave Macmillan, 2003.

KELSEN, H. "Foundations of democracy." Ethics, Vol. 66, Nr. 1, pp. 1-101, 1955. . "O problema do parlamentarismo.” In: A democracia. Trans. V. Barkow. São Paulo: Martins Fontes, 2000, pp. 109-136.

."The Essence and Value of Democracy." Trans. B. Graf. Lanham, MD: Rowman \& Littlefield, 2013.

LANDEMORE, H. "Beyond the fact of disagreement? The epistemic turn in deliberative democracy." Social Epistemology, Vol. 31, Nr. 3, pp. 277-295, 2017.

MARGALIT, A. “On Compromise and Rotten Compromises." Princeton, NJ: Princeton University Press, 2010.

McCORMICK, J. P. "Carl Schmitt's Critique of Liberalism: Against Politics as Technology." Cambridge: Cambridge University Press, 1997.

McNAY, L. "The Misguided Search for the Political." Cambridge: Polity Press, 2014. MIGUEL, L. F. "Democracia e representação: Territórios em disputa." São Paulo: Editora Unesp, 2014.

. "O liberalismo e o desafio das desigualdades." In: L. F. Miguel (ed.). Desigualdades e democracia: O debate da teoria política. São Paulo: Editora Unesp, 2016. pp. 25-66.

. "Consenso e conflito na democracia contemporânea." São Paulo: Editora Unesp, 2017.

. "Dominação e resistência: Desafios para uma política emancipatória." São Paulo: Boitempo, 2018.

MIHAI, M. “Theorizing agonistic emotions.” Parallax, Vol. 20, Nr. 2, pp. 31-48, 2014. MILL, J. S. "The Collected Works of John Stuart Mill.” 33 Vols. Toronto: University of Toronto Press; London: Routledge and Kegan Paul, 1963-1991.

MILLER, J. 2005. "Chairing the Jamaica Committee: J. S. Mill and the limits of colonial authority." In B. Schultz and G. Varouxakis (eds.). Utilitarianism and Empire. Oxford: Lexington Books, 2005. pp. 155-178.

MORLEY, J. “On Compromise.” London: Macmillan, 1898.

MOUFFE, C. 2000. “The Democratic Paradox.” London: Verso, 2000.

MOUFFE, C. and URBINATI, N. "Discutono di democrazia rappresentativa e conflittuale." Il Mulino, Vol. 58, Nr. 5, pp. 807-821, 2009.

PITTS, J. "A Turn to Empire: The Rise of Imperial Liberalism in Britain and France." Princeton, NJ: Princeton University Press, 2005.

RORTY, R. "Philosophy as Cultural Politics: Volume 4: Philosophical Papers." Cambridge: Cambridge University Press, 2007.

ROSANVALLON, P. "Le moment Guizot." Paris: Gallimard, 1985.

. "Le peuple introuvable : Histoire de la représentation démocratique en France." Paris: Gallimard, 1998.

ROSTBØLL, C. F. "Democratic respect and compromise." Critical Review of International Social and Political Philosophy, Vol. 20, Nr. 5, pp. 619-635, 2017. 
SANI, G. "Consenso." In: N. Bobbio, N. Matteucci, and G. Pasquino (eds.). Dizionario di politica. Turino: UTET, 1983, pp. 226-228.

SCHMITT, C. "The Crisis of Parliamentary Democracy." Trans. E. Kennedy. Cambridge, MA: MIT Press, 1985.

. "The Concept of the Political: Expanded Edition.” Trans. G. Schwab. Chicago: University of Chicago Press, 2007.

STEPHEN, J. F. “Liberty, Equality, Fraternity.” Indianopolis: Liberty Fund, [1874] 1993. TAMBAKAKI, P. "Agonism and the crisis of representative democracy." In: A. Azmanova and M. Mihai (eds.). Reclaiming Democracy: Judgment, Responsibility and the Right to Politics. London: Routledge, 2015, pp. 17-33.

TEN, C. L. "Mill on Liberty." Oxford: Clarendon Press, 1980.

THUCYDIDES. "História da Guerra do Peloponeso." Trans. M. G. Kury. Brasília: Editora da Universidade de Brasília, 1982.

THOMPSON, D. "Mill in parliament: When should a philosopher compromise?" In: N. Urbinati and A. Zakaras (eds.). J. S. Mill's Political Thought: A Bicentennial Reassessment. Cambridge: Cambridge University Press, 2007, pp. 166-199.

URBINATI, N. "Mill on Democracy: From the Athenian Polis to Representative Government." Chicago: University of Chicago Press, 2002.

. "Representative Democracy: Principles \& Genealogy." Chicago: University of Chicago Press, 2006.

. "Democracy Disfigured: Opinion, Truth, and the People." Cambridge, MA: Harvard University Press, 2014.

URBINATI, N. and ACCETTI, C. I. "Editors' introduction." In: H. Kelsen. The Essence and Value of Democracy. Trans. B. Graf. Lanham, MD: Rowman \& Littlefield, 2013, pp. 1-24.

VINX, L. "Hans Kelsen's Pure Theory of Law: Legality and Legitimacy." Oxford: Oxford University Press, 2007.

WENMAN, M. "Agonistic Democracy: Constituent Power in the Era of Globalisation." Cambridge: Cambridge University Press, 2013.

WILliaMS, R. "Consensus." In: Keywords: A Vocabulary of Culture and Society. Revised edition. Oxford: Oxford University Press, 1983, pp. 76-78.

WINGENBACH, E. "Institutionalizing Agonistic Democracy: Post-foundationalism and Political Liberalism." Surrey: Ashgate, 2011.

ZERILLI, L. M. G. “A Democratic Theory of Judgment.” Chicago: University of Chicago Press, 2016. 